\title{
KEARIFAN MUHAMMADIYAH DI SUMATERA UTARA DALAM MERESPONS ISU RADIKALISME
}

\author{
Al Rasyidin \\ Universitas Islam Negeri Sumatera Utara Medan, Indonesia \\ E-mail: ralrasyidin@yahoo.com \\ Hasnah Nasution \\ Universitas Islam Negeri Sumatera Utara Medan, Indonesia \\ E-mail: hasnahnasuiton26@yahoo.com
}

\begin{abstract}
Radicalism and terrorism have anxiously attracted the world community. Ironically, the terms have been labeled to Islam and the Muslims. This article focuses on how does Muhammadiyah as one of the Indonesian largest Islamic organizations respond to the issue of radicalism in Indonesia? Based on field research where the data is gathered through interview, observation, and documentary study, the research puts emphasis on the responses of Muhammadiyah toward the idea and movement which attempt to establish Islamic state; its responses to the Western countries and the unbelievers; its interpretation of jih $\bar{a} d$ as an obligatory war against the unbelievers; and its idea on legalization of suicide bombings. The study indicates that Muhammadiyah, particularly in the North Sumatera, rejects any radical movement along with its ideology in Indonesia. Muhammadiyah sees that NKRI (The Unity State of the Republic of Indonesia) has been an ideal model of state and it is a blessing of God that must be preserved and protected. Muhammadiyah condemns anyone who justifies violent acts and commits murder and suicide bombings in the name of religion. Muhammadiyah also asserts that radicalism is a threat toward world peace and it has no correlation with the Islamic teachings.
\end{abstract}

Keywords: Muhammadiyah; radicalism; Islamic state; jih äd; suicide bombings.

\section{Pendahuluan}

Istilah radikalisme dan terorisme telah menjadi persoalan penting yang menyita perhatian dan energi negara-negara di dunia. Ketika mendiskusikan term radikalisme dan terorisme, perhatian dunia 
tertuju pada negara-negara Islam atau negara-negara dengan mayoritas penduduknya Muslim. Hal ini disebabkan karena paham dan gerakan radikalisme dan terorisme di dunia dikenalkan dan dilakukan oleh sekelompok orang yang beragama Islam. Kedua term ini mencuat pasca-tragedi 11 September 2001 di Amerika Serikat, dan Al-Qaeda dituduh sebagai biang dari tindakan pemboman World Trade Center dan Pentagon. Implikasi peristiwa ini adalah penyerangan terhadap negara Afghanistan. Pasca-kejadian pemboman tersebut, dunia terus disibukkan dengan persoalan terorisme yang dinilai sebagai efek muncul dan berkembangnya paham radikalisme.

Eksistensi paham dan gerakan radikalisme memunculkan beragam respons. Di Eropa dan Amerika, sejumlah pihak menunjukkan kebencian terhadap Islam dan kaum Muslim. Menurut Christopher Smith, sentimen anti-Islam semakin membesar pasca-tragedi 11 September, dan media massa turut meningkatkan pengaruh tersebut. Tercatat bahwa terdapat 481 kejahatan yang menunjukkan kebencian terhadap Islam dan Muslim di Amerika. ${ }^{1}$ Di Eropa, muncul English Defence League/EDL sebagai gerakan anti-Islam di Inggris. ${ }^{2}$ Sedangkan di Jerman pada tahun 2014 muncul gerakan PEGIDA (Patriotic Europeans Against the Islamisation of the West) yang telah menggerakkan ribuan orang dalam rangka menebar propaganda anti-Islam. ${ }^{3}$ Kebencian terhadap Islam dan kaum Muslim ditunjukkan oleh dua media Barat seperti Jyllands-Posten's dan Charlie Hebdo yang menerbitkan karikatur Nabi Muhammad. ${ }^{4}$ Gerakan anti-Islam di Amerika dan Eropa tidak lain karena adanya tindakan terorisme yang dilakukan oleh sejumlah oknum Muslim yang mengatasnamakan jihad. Tetapi, tidak bisa dinafikan adanya sejumlah tokoh dan ilmuwan Barat yang menolak pengaitan Islam dengan terorisme.

${ }^{1}$ Christopher Smith, "Anti-Islamic Sentiment and Media Framing during the 9/11 Decade", Journal of Religios and Society, Vol. 15 (2014), 1-12.

2 Malte Thran dan Lukas Boehnke, "The Value-Based Nationalism of Pegida," Journal for Deradicalization, Vol. 3 (2015); Malte Thran dan Lukas Boehnke, "Reactive Community Mobilization in Europe: the Case of the English Defence League," Journal Behavioral Sciences of Terrorism and Political Aggression, Vol. 5, No. 3 (2013).

${ }_{3}^{3}$ Bolshova N.N., "The Rise of Anti-Islamic Protests in Europe under the Refugee Crisis: Case of "Pegida" Movement in Germany", Political Studies, No. 3 (2016), 123137.

${ }^{4}$ Alessandro Zagato, The Event of Charlie Hebdo: Imaginaries of Freedom and Control (New York: Berghahn, 2015), 56-60. 
Literatur-literatur Barat menunjukkan keberadaan kelompokkelompok teroris di dunia. Cory Gideon Gunderson menyebutkan sejumlah kelompok teroris di dunia, antara lain al-Qaeda, Hamas, dan Hiøbullah. ${ }^{5}$ Gerakan teroris terkini adalah Islamic State of Iraq and Syiria (ISIS). ${ }^{6}$ Di Asia Tenggara, sejumlah literatur menyebut kelompok Jamaah Islamiyah, Abu Sayaf dan Moro Islamic Liberation Front (MILF) sebagai kelompok teroris. ${ }^{7} \mathrm{Di}$ Indonesia, keberadaan kelompokkelompok teroris tersebut cukup menyita perhatian pemerintah, sebab mereka melakukan serangkaian pemboman terhadap objek-objek vital, di antaranya Bom Bali (2002), dan Hotel JW Marriot dan RitzCarlton (2009) di Jakarta, ${ }^{8}$ dan terakhir di Surabaya (2018). Berbagai tindakan teror membuat pemerintah mengeluarkan banyak kebijakan dalam rangka pencegahan dan penanggulangan terorisme di Indonesia.

Pemerintah Indonesia masih terus mengambil kebijakan tegas terhadap paham radikalisme. Di antara kelompok yang dianggap radikal as-Sunnah, Ibyaut Turats, al-Sofwah, Lajnah al-Khairiyah, Lajnah alIstiqamah, dan $W$ abdah Islamiyah. Kelompok-kelompok ini dikenal dengan salafi-wahabisme. Kelompok lainnnya yang membenarkan bom bunuh diri adalah Jamaah Ansharut Taubid (JAT) dan Jamaah Islamiyah (JI) dan dimasukkan dalam katagori salafi-jihadis.' Abdul Syukur menyebutkan bahwa kelompok radikal di Indonesia dibagi menjadi dua: gerakan radikal terbuka seperti Laskar Jihad, Forum Komunikasi Ahlus Sunnah wal Jama'ah (LJ-FKAWJ), Front Pembela Islam (FPI), Majelis Mujahidin Indonesia (MMI), Jama'ah Ikhwanul Muslimin, dan Hizbut Tahrir Indonesia (HTI); dan gerakan radikal tertutup seperti Jamaah Islamiyah. ${ }^{10}$ Gerakan-gerakan ini aktif mengembangkan pahamnya di Indonesia dengan beragam cara.

${ }^{5}$ Cory Gideon Gunderson, Terrorist Groups (USA: Abdo dan Daugters, 2003).

6 Gerard Chaliand, "Jihadism in the Age of ISIS," dalam Gerard Chaliand dan Arnaud Blind, The History of Terrorism: From Antiquity to ISIS (California: University of California Press, 2016), 435-339.

${ }^{7}$ Bruce Vaughn, Terrorism in Southeast Asia (Congressional Research Service, 2009); Wilson John dan Swati Parashar, Terrorism in Southeast Asia: Implications for South Asia (Singapura: Pearson Education, 2005), 46-55.

${ }^{8}$ Ibid., 8-10.

9 Rusli, "Indonesian Salafism on Jihad and Suicide Bombings," Journal of Indonesian Islam, Vol. 8, No. 1 (2014), 98-108.

10 Abdul Syukur, "Gerakan Dakwah dalam Upaya Pencegahan Dini terhadap Penyebaran dan Penerimaan Islamisme Kelompok Radikal-Terorisme di Lampung”, Analisis: Jurnal Studi Keislaman, Vol. 15, No. 1 (2015), 225. Lihat juga Zuly Qodir, 
Komunitas pesantren sempat tertuduh sebagai media penyebaran benih-benih radikalisme di Indonesia. Pondok pesantren dinilai sebagai sarang paham radikal, bahkan sejumlah pesantren yang berbasis salafiyah-wahabiyah memberikan kontribusi bagi radikalisme di Indonesia. ${ }^{11}$ Menurut Darmadji bahwa kemunculan radikalisasi pemahaman pada pondok pesantren tertentu yang berdampak pada aksi terorisme di Indonesia harus diletakkan dalam konteks perkembangan gerakan Islam transnasional sebagai akibat dari berbagai perkembangan dunia. ${ }^{12}$ Akan tetapi, beberapa penelitian menunjukkan bahwa kurikulum pendidikan pesantren tidak diarahkan pada paham radikalisme. ${ }^{13}$ Ronald Lukens-Bull menemukan bahwa pesantren sebagai lembaga pendidikan Islam yang kerap dituduh sebagai sumber terorisme ternyata mengajarkan sikap akomodatif, pluralis, dan anti-radikal. ${ }^{14}$ Meskipun harus diakui bahwa beberapa pesantren yang berafiliasi dengan wahabisme turut berkontribusi bagi pertumbuhan paham radikalisme di Indonesia, tetapi menyatakan bahwa pesantren sebagai sarang radikalisme adalah sebuah generalisasi yang tidak bisa diterima.

Setelah pesantren sempat tertuduh sebagai sarang radikalisme, muncul tuduhan lain bahwa paham radikalisme dan islamisme muncul dalam organisasi-organisasi Islam yang terdaftar resmi di Indonesia. Beberapa organisasi-organisasi Islam di Indonesia terlibat dalam kegiatan mendukung penegakan syariat Islam di Indonesia seperti Jamaah Salafi, Front Pembela Islam Surakarta, dan Komite Persiapan Penegakan Syariat Islam Sulawesi Selatan. Sebagian organisasi dan gerakan Islam lainnya terlibat dalam upaya menegakkan negara Islam di Indonesia seperti Majelis Mujahidin Indonesia (MMI) dan Hizbut

\footnotetext{
“Gerakan Salafi Radikal dalam Konteks Islam Indonesia: Tinjauan Sejarah”, Islamica: Jurnal Studi Keislaman, Vol. 3, No. 1 (2008), 1-15.

11 Edi Susanto, "Kemungkinan Munculnya Paham Islam Radikal di Pondok Pesantren,” dalam Tadris: Jurnal Pendidikan Islam, Vol. 2, No. 1, 2007, 1-19.

12 Ahmad Darmadji, "Pondok Pesantren dan Deradikalisasi Islam di Indonesia," Millah: Jurnal Studi Agama, Vol. 11, No. 1 (2011), 248.

13 Ayub Mursalin dan Ibn Katsir, "Pola Pendidikan Keagamaan Pesantren dan Radikalisme: Studi Kasus Pesantren-pesantren di Provinsi Jambi", Kontekstualita: Jurnal Penelitian Sosial Keagamaan, Vol. 25, No. 2 (2010), 286.

14 Ronald Lukens-Bull, "The Traditions of Pluralism, Accomodation, and AntiRadicalism in the Pesantren Community," Journal of Indonesian Islam, Vol. 2, No. 1 (2008), 14; bandingkan dengan Saifulah, "Dakwah Multikultural Pesantren Ngalah" Islamica: Jurnal Studi Keislaman, Vol. 8, No. 2 (2014), 421-446.
} 
Tahrir Indonesia (HTI). ${ }^{15}$ Kelompok dan organisasi di atas telah diklaim pemerintah sebagai kelompok radikal, HTI bahkan telah dibubarkan oleh pemerintahIndonesia.

Organisasi-organisasi Islam seperti NU, Muhammadiyah, AlWashliyah, dan Al-Ittihadiyah memang tidak pernah disebut sebagai organisasi-organisasi Islam radikal. Keempatnya kerap disebut organisasi Islam yang moderat. ${ }^{16}$ Sebagai sebuah organisasi moderat, keempatnya telah menunjukkan sikap menerima dan mendukung negara kesatuan Republik Indonesia. Akan tetapi, sebagai organisasi Islam moderat yang terbesar di Indonesia dengan dukungan konstituen yang beragam, kemungkinan adanya paham radikalisme yang dianut oleh tokoh-tokoh keempat organisasi ini, baik di level pusat maupun daerah, tidak boleh dinafikan begitu saja. Asumsi ini sekaligus untuk membuktikan bahwa apakah keempat organisasi ini benar-benar mendukung moderatisme dari level bawah sampai pada level atas, dan benarkah tokoh-tokoh organisasi Nahdlatul Ulama, Muhammadiyah, Al-Washliyah, dan Al-Ittihadiyah berpaham moderat sembari menolak paham yang digulirkan oleh kelompok radikalisme di dunia maupun di Indonesia. Kajian selama ini masih ditujukan pada pergerakan keempat organisasi tersebut di level pusat yang sudah menunjukkan bahwa keempat organisasi Islam ini merupakan organisasi moderat yang menentang paham radikalisme. Begitupun, masih tetap muncul pertanyaan apakah benar seluruh eksponen keempat organisasi Islam ini menolak total paham radikalisme

Secara umum artikel ini mengkaji respons Muhammadiyah di Sumatera Utara terhadap radikalisme? Sedangkan secara spesifik, artikel ini mengkaji respons Muhammadiyah terhadap paham dan

15 Endang Turmudi dan Riza Sihbudi (eds.), Islam dan Radikalisme di Indonesia (Jakarta: LIPI Press, 2005), 153-278. Bandingkan dengan Masdar Hilmy, "Manufacturing The 'Ontological Enemy': Socio-Political Construction of antiDemocracy Discourses among HTI Activists in Post-New Order Indonesia", Journal of Indonesian Islam, Vol. 3, No. 2 (2009); Sahid H.M., "Contesting Caliphate: Opposition of Indonesian Fundamentalist Groups to ISIS Caliphate", Journal of Indonesian Islam, Vol. 8, No. 2 (2014).

${ }^{16}$ Masdar Hilmy, "Whither Indonesia's Islamic Moderatism? A Reexamination on the Moderate Vision of Muhammadiyah and NU", Journal of Indonesian Islam, Vol. 7, No. 1 (2013); Masdar Hilmy, "Quo-Vadis Islam Moderat Indonesia? Menimbang Kembali Modernisme Nahdlatul Ulama dan Muhammadiyah", MIQOT: Jurnal Ilmuilmu Keislaman, Vol. 36, No. 2 (2012); Toto Suharto, "Gagasan Pendidikan Muhammadiyah dan NU sebagai Potret Pendidikan Islam Moderat di Indonesia", Islamica: Jurnal Studi Keislaman, Vol. 9, No. 1 (2014). 
gerakan radikal yang hendak: mendirikan negara Islam, negara-negara Barat dan kaum kafir; memaknai jihad sebagai kewajiban berperang melawan orang-orang kafir; dan melegalkan bom bunuh diri. Dengan demikian, artikel ini hendak mengkaji tanggapan dan reaksi pimpinan dan/atau pengurus Muhammadiyah terhadap paham dan gerakan radikalisme yang mencakup empat hal: pertama, tanggapan atau jawaban verbal terhadap paham dan gerakan radikalisme yang mengusung ide ingin mendirikan negara Islam, memaknai jihad sebagai perang, anti-kaum kafir dan negara-negara Barat yang memusuhi kaum Muslim, dan yang melegalkan bom bunuh diri. Kedua, reaksi dan atau aktivitas konkret secara organisatoris yang dilakukan Muhammadiyah dalam menyikapi paham dan gerakan radikalisme yang mengusung ide ingin mendirikan negara Islam, memaknai jihad sebagai perang, anti terhadap kaum kafir dan negaranegara Barat yang memusuhi kaum Muslim, dan yang melegalkan bom bunuh diri.

Fokus kajian diperoleh dari pendapat Petrus Reinhard Golose yang mengajukan empat ideologi kelompok radikal dari kalangan salafi-jihadis, bahkan teroris, yakni dawlah Islämìyah, hijrah, jïhäd, dan istimätah. Pertama, kelompok radikalisme bertujuan hendak mendirikan negara Islam (dawlah Islamiyah) sebagai syarat utama penegakan syariat Islam. Sebagai inti paham radikalisme, pendirian negara Islam menjadi sebuah keniscayaan, di mana negara dijalankan sesuai tuntutan syariat Islam, dipimpin seorang khalifah, dan mencakup seluruh kawasan di dunia. Kedua, sebagai dampak dari upaya mendirikan negara Islam, kelompok radikal mengusung gagasan hijrah di mana mereka tidak ragu meninggalkan keluarga dan kesenangan duniawi demi berjuang di jalan Allah dalam rangka mencapai tujuan inti dari pahamnya. Sebagai kelompok yang ber-hijrah, mereka membentuk empat kerangka nilai dalam hijrah: al-walà' wa al-barä' (sikap solidaritas sesama Muslim dan membenci kaum kafir), takfir (sikap mengkafirkan kelompok di luar kelompok sendiri, bahkan menghalalkan harta dan darah kelompok lain), jamäah (sikap menghargai dan mendukung persaudaraan dan solidaritas Islam seluruh dunia tanpa dibatasi oleh negara, suku dan ras), dan bay'ah (sumpah setia terhadap pemimpin kelompok). Ketiga, jïhäd, yakni kewajiban berperang melawan orang-orang kafir khususnya pihak Amerika, Yahudi, dan sekutu keduanya. Keempat, 
istimātah, yakni bom bunuh diri sebagai wujud pengabdian tertinggi, penghapus dosa, dan jalan utama menuju surga. ${ }^{17}$

\section{Muhammadiyah di Sumatera Utara}

Muhammadiyah didirikan oleh KH. Ahmad Dahlan di Yogyakarta pada tanggal 8 Dzulhijjah 1330/18 Nopember $1912 .{ }^{18}$ Berdirinya organisasi ini dilatari oleh saran beberapa murid KH. Ahmad Dahlan. Dalam sebuah dialog, seorang murid bertanya: Kiai, apakah di sini tempat sekolahan? Sekolahan apakah yang ada di sini itu? O, Nak, ini Madrasah Ibtidaiyah Islam untuk memberi pelajaran agama Islam dan pengetabuan umum, bagi anak-anak kita kampung Kauman. Siapakah yang memegang dan siapakah yang menjadi gurunya Kiai? Yang memegang dan menjadi guru agamanya ya saya, jawab KH. Ahmad Dahlan. Mendengar hal itu, sang murid pun berkata:

Apakah tidak lebih baik kalau sekolah itu dipegang oleh Kiai sendiri, sebab itu tiap-tiap tahun harus naik kelasnya, sampai beberapa kelas, yang dimaksud. Jadi seolah-olah sekolahan itu milik Kiai sendiri, maka apabila Kiai meninggal dunia ahli waris tidak mampu meneruskan terhentilah sekolah itu. Sebagaimana pondokpondok Kiyai bila Kiyainya telah wafat lalu santrinya bubar. Maka dari itu, kami usul hendaknya sekolah itu dipegang oleh suatu organisasi hingga dapat langsung selama-lamanya. ${ }^{19}$

Saran muridnya tersebut kemudian didiskusikan $\mathrm{KH}$ Ahmad Dahlan dengan Mas Budiharjo dan Raden Dwijosewoyo serta beberapa pemuda dewasa yang bersedia membantunya untuk mendirikan sebuah oganisasi. Diskusi itu menyepakati perlunya didirikan Muhammadiyah dan menyatakan kesanggupannnya untuk membantu moril dan tenaga dengan syarat setidaknya didukung oleh tujuh anggota biasa Boedi Oetomo. Akhirnya tujuh anggota tersebut mengajukan permohonan izin (Recht Persoon) kepada pemerintah Hindia Belanda untuk mendirikan Persyarikatan Muhammadiyah. Setelah melalui proses permohonan perizinan, akhirnya pada tanggal 18 November 1912 bersamaan dengan 8 Zulhijjah 1330, pemerintah

17 Petrus Reinhard Golose, Deradikalisasi Terorisme: Humanis, Soul Approach dan Menyentuh Akar Rumput (Jakarta: YPKIK [Yayasan Pengembangan Kajian Ilmu Kepolisian], 2010), 47-52.

18 Suara Muhammadiyah dan Majelis Pendidikan Kader PP Muhammadiyah, Manhaj Gerakan Mubammadiyah Ideologi, Khittah, dan Langkah (Yogyakarta: Suara Muhammadiyah, 2010), 287.

19 Haji Muhammad Syoedja, Cerita tentang Kiyai Ahmad Dablan: Catatan Haji Mubammad Syoedja (t.t.: t.tp., t.th.), 65. 
Hindia Belanda mengizinkan berdirinya Muhammadiyah dengan mengeluarkan besluit, recht persoon yang dikirimkan kepada pemohon melalui Boedi Oetomo. ${ }^{20}$

Setelah resmi berdiri, Muhamadiyah banyak melakukan kegiatankegiatan pengajian dan pengajaran. Dalam perkembangan selanjutnya, berbagai kegiatan lainpun turut dilakukan, seperti tabligh, amal sosial, dan lain-lain. Penyelenggaraan seluruh kegiatan tersebut dikoordinir oleh bagian-bagian dalam organisasi Muhammadiyah. Sepanjang masa kepemimpinan KH Ahmad Dahlan, Muhammadiyah telah memiliki setidaknya lima bagian dalam organisasi Muhammadiyah, yaitu: 1) bagian persekolahan (Hoofd Bestuur), 2) bagian tabligh (Hoofd Bestuur), 3) bagian penolong kesengsaraan umum (Hoofd Bestuur), 4) bagian taman pustaka (Hoofd Bestuur), dan 5) bagian penolong haji. ${ }^{21}$

Pada awalnya, Muhammadiyah beroperasi dan melaksanakan ragam aktivitasnya di wilayah Yogyakarta. Perkembangan selanjutnya, dari wilayah ini Muhammadiyah didirikan dan berkembang luas di berbagai wilayah Indonesia, termasuk Sumatera Utara yang ketika itu masih bernama Keresidenan Sumatera Timur. ${ }^{22}$

Dalam situs resmi PW Muhammadiyah Sumatera Utara dikemukakan bahwa di Sumatera Utara Muhammadiyah berdiri secara resmi pada tanggal 1 Juli 1928, meskipun jauh sebelum itu, yakni sejak 25 Nopember 1927, gerakan dahwah atau propaganda Muhammadiyah sudah dimulai di jalan Nagapitan/jalan Kediri Kampung Keling Medan. ${ }^{23}$

\footnotetext{
${ }^{20}$ Ibid., 67-73.

${ }^{21}$ Ibid., 97-118.

22 Dalam catatan Dja'far Siddik dikemukakan bahwa penyebaran dan perkembangan Muhammadiyah di Indonesia memang cukup pesat. Dalam tahun 1925, Muhammadiyah telah memiliki 29 cabang dengan 4.000 anggota. Dalam waktu 13 tahun kemudian yaitu tahun 1938 Muhammadiyah telah memiliki 852 cabang dengan 250.000 anggota. Lihat Dja'far Siddik, "Dinamika Organisasi Muhammadiyah di Sumatera Utara", Journal of Contemporary Islam and Muslim Societies, Vol. 1, No. 1 (2017), 14.

${ }^{23}$ Lihat "Sejarah Perkembangan Muhammadiyah di Sumatera Utara," tersedia online pada http://sumut.muhammadiyah.or.id/content-3-sdet-sejarah.html diunduh pada tanggal 27 September 2018. Dalam catatan Dja'far Siddik dikemukakan bahwa pada tahun 1927 di Medan telah berdiri cabang Muhammadiyah sebagai cabang pertama di Sumatera Utara. Namun dikarenakan Surat Ketetapan Hoofdbestuur Muhammadiyah baru keluar pada tanggal 1 Juli 1928, maka tahun ini dinyatakan sebagai tahun resmi berdirinya Muhammadiyah di Sumatera Utara. Lihat Siddik, "Dinamika Organisasi Muhammadiyah," h. 18.
} 
Berdirinya Muhammadiyah di Sumatera Utara tidak terlepas dari peran para perantau pedagang dari Minangkabau, Jawa, dan Mandailing. ${ }^{24}$ Keinginan mendirikan Muhammadiyah di daerah ini sebenarnya sudah ada sejak tahun 1925 ketika Mas Pono bertemu dengan Djuin St. Penghulu, St. Saidi Djamaris, Dt. Bungsu dan kawan-kawan. Dalam sejumlah pertemuan, mereka merasa prihatin terhadap praktik-praktik keagamaam masyarakat Muslim yang dipandang menyimpang dari al-Qur'ān dan Sunnah, khususnya berkaitan dengan khurafät dan bidah. Diskusi mengenai hal itu akhirnya menggiring mereka sampai pada kesimpulan perlunya Muhammadiyah didirikan di daerah ini. Mereka menyadari bahwa untuk mewujudkan tujuan tersebut tidaklah mudah. Sebab, disamping adanya perbedaaan paham keagamaan dengan mayoritas Muslim di Sumatera Timur, mereka juga menyadari bahwa mereka bukanlah ulama dan belum pula paham seluk beluk berorganisasi. Mereka hanyalah pedagang kecil yang membawa dagangannya berupa barangbarang keperluan sehari-hari ke daerah-daerah perkebunan di sekitar Medan. ${ }^{25}$ Menyadari hal tersebut, mereka kemudian bersepakat untuk mencari orang-orang yang sepaham dengan mereka. Hal tersebut mereka lakukan dengan mengidentifikasi cara seseorang dalam melaksanakan salat. Untuk keperluan tersebut, hampir setiap hari di dekat pajak bundar Medan, mereka mencari dan menghimpun sejumlah teman yang sepaham. Usaha tersebut dilanjutkandengan mendekati HR. Muhammad Said (mantan Vice President Serikat Islam Pematang Siantar dan wartawan Pewarta Deli) agar bersedia memimpin Muhammadiyah jika kelak organisasi ini didirikan. ${ }^{26}$ Sebagaimana dikemuakan Mu'thi, keinginan yang telah ada itu semakin kuat ketika AR Sutan Mansur bersama M. Fakhruddin sebagai utusan Hoofdbestuur Muhammadiyah berkunjung ke Medan dan Aceh pada bulan Mei 1927 untuk mempropagandakan Muhammadiyah kepada para simpatisannya. Hal ini tentu saja

\footnotetext{
${ }^{24}$ Lihat dalam situs resmi Muhammadiyah dalam http://sumut.muhammadiyah .or.id/content-3-sdet-sejarah.html.

${ }^{25}$ Lihat Abdul Mu'thi, "30 Tahun Muhammadiyah di Daerah Sumatera Timur," dalam 30 Tabun Mubammadiyah di Daerab Sumatera Timur (Medan: Panitia Besar Peringatan, 1957), 99.

26 M. Nur Haitamy, 'Muhammadiyah Daerah Sumatera Timur' dalam 30 Tabun Muhammadiyah di Daerah Sumatera Timur (Medan: Panitia Besar Peringatan, 1957), 177.
} 
semakin mempertebal semangat dan hasrat untuk mendirikan Muhammadiyah. ${ }^{27}$

Akhirnya pada tanggal 1 Juli 1928 secara resmi didirkanlah Muhammadiyah di Sumatera Utara dengan ketua pertamanya HR. Muhammad Said, Mas Pono sebagai sekretaris, dan dilengkapi oleh St. Juin dan Kari Suib. ${ }^{28}$ Hasan Asari sebagaimana dikutip Dja`far Siddik ${ }^{29}$ menyebutkan bahwa para pengurus Muhammadiyah pada periode awal itu adalah HR. Muhammad Said (ketua), Djuin Sutan Penghulu (wakil ketua), Mas Pono (sekretaris), Penghulu Manan (wakil sekretaris), Sutan Saidi (bendahara), Tujung Muhd Arif (advisur), dan para komisaris antara lain Kongo St. Maradjo, Hasan St. Batuah, Awan St. Saripado, Hadji Kari Sju'ib, dan St. Ibrahim.

Setelah resmi berdiri, aktivitas utama yang dilaksanakan Muhammadiyah adalah dakwah. Kegiatan ini dilakukan dengan tujuan untuk menyebarkan paham dan memperluas keberadaan organisasi ke berbagai kawasan di Sumatera Utara. Tema-tema pembahasan utama dalam tabligh-tabligh yang dilakukantersebut selalu fokus pada persoalan-persoalan fiqhiyah, seperti usalli, qunüt, meluruskan arah kiblat, salat memakai dasi, kenduri kematian, ziarah kubur dan ke kuburan keramat, salat Hari Raya di lapangan terbuka, salat sunat 11 rakaat pada bulan Ramadan, ${ }^{30}$ di samping beberapa aspek yang berkaitan dengan masalah-masalah kehidupan sosial dan akhlak. Untuk mempermudah pelaksanaan tabligh dan pengajian, Muhammadiyah mendirikan masjid dan musala.

Secara organisatoris, Muhammmadiyah kemudian berkembnag luas ke berbagai daerah di Sumatera Utara. Hanya beberapa tahun setelah berdirinya, di tahun 1930 Muhammadiyah telah memiliki 19 ranting yang bernaung pada 10 cabang. ${ }^{31}$ Jumlah ini meningkat drastis pada tahun 1940 di mana ranting Muhammadiyah di seluruh Sumatera

${ }^{27}$ Mu'thi, 30 Tahun Mubammadiyah, 100.

28 Lihat "Sejarah Perkembangan Muhammadiyah di Sumatera Utara," dalam http:/ / sumut.muhammadiyah.or.id/content-3-sdet-sejarah.html

29 Siddik, "Dinamika Organisasi Muhammadiyah", 18-19.

30 Lihat 'Sejarah Perkembangan Muhammadiyah di Sumatera Utara' dalam http://sumut.muhammadiyah.or.id/content-3-sdet-sejarah.html

31 Dalam situs resmi Pimpinan Wilayah Muhammadiyah Sumatera Utara dikemukakan bahwa pada tahun 1930 telah ada 12 Pimpinan Cabang Muhammadiyah di Sumatera Utara, yaitu Medan, Pancur Batu, Pematang Tanah Jawa, Tebing Tinggi, Kisaran, Pematang Siantar, Kerasaan, Glugur, Tanjung Balai, Binjai, Perdagangan, dan Indra Pura. Lihat http://sumut.muhammadiyah .or.id/content-3-sdet-sejarah.html 
Timur berkembang menjadi 72 ranting. Peningkatan jumlah yang begitu pesat tersebut dilatari oleh semakin gencarnya propaganda yang dilakukan Muhammadiyah dan semakin dikenalnya Muhammadiyah di masyarakat. Jika pada masa-masa sebelumnya anggota-anggota Muhammadiyah didominasi oleh para perantau Minang, Mandailing dan Jawa, maka pada masa ini kalangan turunan bangsawan dan putera-puteri asli Sumatera Timur telah ada yang bergabung dalam Muhammadiyah, di antaranya Tengku Katan, Tengku Yahya, dan Tengku Johani. ${ }^{32}$

Perkembangan selanjutnya, sampai tahun 1955 Muhammadiyah telah memiliki 112 Ranting, yang mengasuh tiga Taman Kanakkanak/Bustanul Atfal, 28 Diniyah-Ibtidaiyah, satu Madrasah Tsanawiyah, 24 Sekolah Dasar, delapan SMP, serta sejumlah Panti Asuhan yang menampung anak miskin dan yatim piatu.Pada mulanya, daerah yang merupakan wilayah pengembangan Muhammadiyah meliputi Pancurbatu, Pematang Tanah Jawa, Tebing Tinggi, Kisaran, Pematang Siantar, Kerasaan, Glugur, Tanjung Balai, Binjai dan Perdagangan. Sementara dari Sibolga, yang ketika itu masih merupakan keresidenan Tapanuli, Muhammadiyah berkembang ke Padangsidempuan, Sipirok, dan Tamiang. ${ }^{33}$ Saat ini, Pimpinan Wilayah Muhammadiyah Sumatera Utara telah mengembangkan sayap organisasinya ke berbagai kabupaten dan kota di Sumatera Utara. Sampai tahun 2016, Muhammadiyah Sumatera Utara tercatat telah memiliki 29 Pimpinan Daerah dengan 148 Pimpinan Cabang dan 746 Ranting. ${ }^{34}$

Tabel 1

Jumlah Pimpinan Daerah dan Pimpinan Cabang Muhammadiyah Sumatera Utara sampai Tahun 2016

\begin{tabular}{|c|l|c|c|l|c|}
\hline No & $\begin{array}{l}\text { Pimpinan } \\
\text { Daerah }\end{array}$ & $\begin{array}{l}\text { Pimpinan } \\
\text { Cabang }\end{array}$ & No & $\begin{array}{l}\text { Pimpinan } \\
\text { Daerah }\end{array}$ & $\begin{array}{l}\text { Pimpinan } \\
\text { Cabang }\end{array}$ \\
\hline 1. & Kota Medan & 31 & 16 & $\begin{array}{l}\text { Kab. Tapanuli } \\
\text { Utara }\end{array}$ & 4 \\
\hline 2. & Kota Binjai & 5 & 17 & $\begin{array}{l}\text { Kab. Mandailing } \\
\text { Natal }\end{array}$ & 8 \\
\hline
\end{tabular}

32 Mu'thi, 30 Tahun Muhammadiyah, 135.

33 Tanwir Ahmad Nasution, Sejarah Berdirinya Daerah Muhammadiyah Kabupaten Tapanuli Selatan (t.t.: t.tp., 2005), 1.

34 Lihat Pimpinan Wilayah Muhammadiyah Sumatera Utara, Laporan Pimpinan Wilayah Mubammadiyah Sumatera Utara Tabun 2016 (Medan: Pimpinan Wilayah Muhammadiyah Sumatera Utara, 2016), 56-73. 


\begin{tabular}{|c|c|c|c|c|c|}
\hline 3. & $\begin{array}{l}\text { Kota } \\
\text { Pematang } \\
\text { Siantar }\end{array}$ & 3 & 18 & $\begin{array}{l}\text { Kab. Serdang } \\
\text { Bedagai }\end{array}$ & 7 \\
\hline 4. & $\begin{array}{l}\text { Kota Tebing } \\
\text { Tinggi }\end{array}$ & 4 & 19 & $\begin{array}{l}\text { Kab. Tanjung } \\
\text { Balai }\end{array}$ & 4 \\
\hline 5. & $\begin{array}{l}\text { Kabupaten } \\
\text { Asahan }\end{array}$ & 10 & 20 & $\begin{array}{l}\text { Kab. Pak-Pak } \\
\text { Barat }\end{array}$ & 3 \\
\hline 6. & $\begin{array}{l}\text { Kab. } \\
\text { Tapanuli } \\
\text { Tengah }\end{array}$ & 10 & 21 & Kab. Batubara & 3 \\
\hline 7. & Kota Sibolga & 3 & 22 & $\begin{array}{l}\text { Kab. Padang } \\
\text { Lawas }\end{array}$ & 3 \\
\hline 8. & $\begin{array}{l}\text { Kab. } \\
\text { Tapanuli } \\
\text { Selatan }\end{array}$ & 8 & 23 & $\begin{array}{l}\text { Kota } \\
\text { Padangsidimpuan }\end{array}$ & 4 \\
\hline 9. & $\begin{array}{l}\text { Kabupaten } \\
\text { Langkat }\end{array}$ & 8 & 24 & $\begin{array}{l}\text { Kab. L. Batu } \\
\text { Selatan }\end{array}$ & 3 \\
\hline 10. & $\begin{array}{l}\text { Kab. Deli } \\
\text { Serdang }\end{array}$ & 6 & 25 & Kab. L. Batu Utara & 3 \\
\hline 11. & Labuhan Batu & 6 & 26 & $\begin{array}{l}\text { Kab. Gunung } \\
\text { Sitoli }\end{array}$ & - \\
\hline 12. & $\begin{array}{l}\text { Kab. } \\
\text { Simalungun }\end{array}$ & 6 & 27 & Kab. Nias Barat & - \\
\hline 13. & $\begin{array}{l}\text { Kabupaten } \\
\text { Nias }\end{array}$ & 2 & 28 & Kab. Nias Utara & - \\
\hline 14. & $\begin{array}{l}\text { Kabupaten } \\
\text { Karo }\end{array}$ & 2 & 29 & Kab. Nias Selatan & - \\
\hline 15. & $\begin{array}{l}\text { Kabupaten } \\
\text { Dairi }\end{array}$ & 2 & & Jumlah & \\
\hline
\end{tabular}

Untuk memperlancar aktivitas tableagh dan pengajian kepada para anggota dan masyarakat, Muhammadiyah kemudian mendirikan sejumlah masjid dan musala. Pada tahun 2005, Muhammmadiyah Sumatera Utara telah membangun 257 masjid Taqwa dan 137 unit musala. Di setiap masjid dan musala tersebut, secara terjadwal dan kontinu diselenggarakan kegiatan tabligh dan pengajian-pengajian, baik untuk pembinaan internal warga Muhammadiyah maupun masyarakat luas. Pada tahun 2010, Muhammadiyah Sumatera Utara tercatat telah 
memiliki 294 masjid dan 52 unit musala. ${ }^{35}$ Jumlah tersebut meningkat menjadi 302 masjid dan 52 unit musala di tahun 2016.36

Dalam menyebarluaskan paham dan mengembangkan organisasinya, Muhammadiyah kemudian mendirikan sekolah modern model Belanda. Keberadaan sekolah modern ini ternyata menarik minat masyarakat yang ditandai dengan semakin banyaknya orang tua yang mendaftarkan anaknya ke sekolah Muhammadiyah. Dalam perkembangan berikutnya, Muhammadiyah tidak hanya mendirikan lembaga pendidikan dalam bentuk sekolah, tetapi juga madrasah, pondok pesantren, dan perguruan tinggi. Tahun 1990, Muhammadiyah telah mengelola 63 unit TK-Bustanul Athfal, 109 unit Sekolah Dasar (SD/MI/MD), 64 unit SLTP (SMP/MTs), 36 unit SLTA (SMU/SMK/MA), dan tiga unit Pondok Pesantren. Kemudian di tahun 2005, lembaga-lembaga pendidikan Muhammadiyah bertambah hingga memiliki 81 unit TK, 220 unit Sekolah Dasar, 75 unit SLTP, 41 unit SLTA, tiga unit Pondok Pesantren, satu unit Sekolah Luar Biasa, dan lima unit perguruan tinggi. ${ }^{37}$ Sampai tahun 2010, Muhammadiyah Sumatera Utara tercatat memiliki 360 lembaga pendidikan dari tingkat dasar, menengah sampai perguruan tinggi. Secara rinci mengenai hal ini dapat dilihat pada tabel berikut:

Tabel 2:

Jumlah Lembaga Pendidikan Dasar, Menengah, dan Perguruan Tinggi Muhammadiyah Sumatera Utara sampai tahun $2016^{38}$

\begin{tabular}{|l|l|l|l|}
\hline No. & Jenis Lembaga Pendidikan & Jumlah & Total \\
\hline
\end{tabular}

35 Lihat Pimpinan Wilayah Muhammadiyah Sumatera Utara, Laporan Pimpinan Wilayah Mubammadiyah Sumatera Utara Periode 2005-2010 (Medan: Pimpinan Wilayah Muhammadiyah Sumatera Utara, 2011).

36 Pimpinan Wilayah Muhammadiyah Sumatera Utara, Laporan Pimpinan Wilayah Muhammadiyah Sumatera Utara Tabun 2016 (Medan: Pimpinan Wilayah Muhammadiyah Sumatera Utara, 2016).

37 Abbas Pulungan et. al., Sejarah dan Dinamika Organisasi Islam di Sumatera Utara (Medan: Institut Agama Islam Negeri Sumatera Utara, 2005), 165-166.

38 Pimpinan Wilayah Muhammadiyah Sumatera Utara, 'Rekapitulasi Data Amal Usaha Pimpinan Wilayah Muhammadiyah Sumatera Utara' dalam Laporan Pimpinan Wilayah Muhammadiyah Sumatera Utara Periode 2005-2010 pada Musyawarah Wilayah ke11 Pimpinan Wilayah Muhammadiyah Sumatera Utara (Medan: Pimpinan Wilayah Muhammadiyah Sumatera Utara, 2010). 


\begin{tabular}{|c|l|c|c|}
\hline 1. & Pendidikan Dasar dan Menengah & & \\
& Umum & 104 & \\
& Sekolah Dasar & 57 & \\
& Sekolah Menengah Pertama & 21 & 195 \\
& Sekolah Menengah Atas & 13 & \\
& Sekolah Menengah Kejuruan & & \\
& & & \\
\hline 2. & Pendidikan Dasar dan Menengah & 101 & \\
& Keagamaan & 16 & \\
& 2.1. Madrasah Diniyah Awaliah & 28 & 157 \\
& 2.2. Madrasah Ibtidaiyah & 12 & \\
\hline & 2.3. Madrasah Tsanawiyah & 3 & 3 \\
\hline 3. & 2.4. Madrasah Aliyah & 5 & 5 \\
\hline 4. & Pondok Pesantren & & 360 \\
\hline \multicolumn{2}{|c|}{ Perguruan Tinggi } & \\
\hline
\end{tabular}

Selain aktivitas dakwah dan pendidikan, Muhammadiyah Sumatera Utara juga aktif melakukan berbagai kegiatan amal usaha sosial ekonomi dan kesehatan. Dalam bidang sosial ekonomi, Muhammadiyah Sumatera Utara mendirikan koperasi, Bank Muamalat wa Tamwil (BMT), dan panti asuhan. Sampai tahun 2016, Muhammadiyah Sumatera Utara tercatat telah memiliki 79 unit usaha koperasi, enam unit BMT, dan delapan unit panti asuhan. ${ }^{39}$ Sedangkan amal usaha di bidang kesehatan, Muhammadiyah Sumatera Utara mendirikan sejumlah sarana kesehatan dari mulai rumah sakit, klinik, rumah bersalin, dan apotek. Pada tahun 2010, Muhammadiyah Sumatera Utara telah memiliki satu unit rumah sakit di Medan, lima unit klinik yang berada di Binjai, Tebing Tinggi, Sibolga, Batu Bara, dua unit rumah bersalin di Medan, dan satu unit apotek di Binjai. ${ }^{40}$ Kegiatan di bidang ini tentu saja ditujukan untuk pemberdayaan ekonomi dan kesejahteraan umat, penyantunan dan pemeliharaan anak yatim dan piatu, serta pengobatan penyakit dan pemeliharaan kesehatan masyarakat.

39 Lihat Pimpinan Wilayah Muhammadiyah Sumatera Utara, Laporan Pimpinan Wilayah Mubammadiyah Sumatera Utara Tabun 2016 (Medan: Pimpinan Wilayah Muhammadiyah Sumatera Utara, 2016).

${ }^{40}$ Lihat dan situs resmi Pimpinan Wilayah Muhammadiyah Sumatera Utara dalam http:/ / sumut.muhammadiyah.or.id/content-16-sdet-kesehatan.html. 


\section{Respons Muhammadiyah terhadap Radikalisme Agama}

Bagi Muhammadiyah, Negara Kesatuan Republik Indonesia (NKRI) sebenarnya telah menjadi sebuah keputusan final. Semenjakmasa awal berdiri, misalnya di tahun 1921, 1923 sampai 1926, dalam berbagai kesempatan Muhammadiyah telah menyebutkan Indonesia ketika itu. Kemudian seiring dengan perjalanan waktu, berdirinya NKRI juga dibidani oleh para tokoh Muhammadiyah, seperti Ki Bagus Hadi Kusumo, Kasman Singadimejo, dan Buya Hamka. Mereka semua berpikir keras bagaimana caranya untuk mendirikan negara Indonesia di mana setiap komponen masyarakat yang berbeda suku, bangsa, budaya, dan agama bisa dipersatukan. Karena itu, mereka sepakat mendirikan NKRI, bukan negara Islam. Sepanjang sejarah, tokoh-tokoh Muhammadiyah sama sekali tidak pernah berpikir untuk mendirikan negara Islam (Islamic State), hanya saja yang mereka pikirkan adalah bagaimana mewujudkan Islamic society, yakni tatanan masyarakat di mana tegaknya nilai-nilai Islam dalam kehidupan mereka. Kemudian pada Mukatamar Muhammadiyah ke-47 di Makasar beberapa waktu yang lalu ditegaskan bahwa Muhammadiyah adalah sebuah organisasi yang menggulirkan sebuah ide NKRI sebagai Där al-'Ahd wa al-Shahädah. Där al-'Ahd maksudnya adalah NKRI merupakan sebuah kesepakatan bersama atau konsensus sosial. Kemudian Shahädah bermakna NKRI merupakan sebuah wilayah di mana seluruh lapisan masyarakat Indonesia yang terdiri atas bermacam suku, bangsa, budaya, bahkan agama mesti berbuah bagi kepentingan NKRI. Karenanya tidak ada agenda bagi warga Muhammadiyah, baik secara ideologi maupun institusional untuk mendirikan negara Islam atau mendukung pendirian negara Islam. Dalam matan keyakinan dan cita-cita hidup Muhammadiyah, sebuah rumusan ideologis yang bagi Muhammadiyah menjadi sesuatu yang wajib untuk dikaji, pada butir kelima dijelaskan bahwa Muhammadiyah mengakui NKRI dan menganggapnya sebagai sebuah anugerah Tuhan yang sangat besar. Sebab itu Muhammadiyah mengajak seluruh lapisan bangsa Indonesia untuk mewujudkan masyarakat Islam yang sebenar-benarnya sehingga lahir sebuah ideologi apa yang dalam al-Qur'ān disebut sebagai baldah tayyibah wa rabb ghafür. ${ }^{41}$

${ }^{41}$ Hasyimsyah Nasution (Ketua PW Muhammadiyah Sumatera Utara), Wawancara, Sumatera Utara 19 Juli 2018; Irwan S. (Sekretaris Umum PW Muhammadiyah Sumatera Utara), Wawancara, Sumatera Utara 23 Juli 2018; Muhammad Qarib 
Perlukah kita menerapkan syariat Islam di Indonesia? Menjawab pertanyaan ini, menurut Muhammadiyah penting terlebih dahulu dipahami apa yang disebut dengan syariat Islam. Kalau yang dimaksud syariat Islam dalam konteks fiqh, menurut Muhammadiyah tidak penting. Namun, jika yang dimaksud syariat Islam dalam pengertian grand concept, maka Muhammadiyah setuju akan penerapannya. Dalam konteks ini yang dimaksud dengan syariat Islam adalah nilai-nilai universal Islam seperti keadilan, toleransi, kemajemukan, kebersamaan, dan persamaan derajat. Inilah elemen-elemen penting dari nilai-nilai syariat Islam sebagai grand concept itu. Jadi, bagi Muhammadiyah yang dimaksud dengan syariat Islam bukan dalam arti 'fiqh kargo' yang diformalkan, didukung, dan disahkan lewat kepentingan-kepentingan politik lalu bersifat mengikat sebagaimana diberlakukan di beberapa daerah, seperti Aceh Darussalam. ${ }^{42}$

Menurut Muhammadiyah, secara teknis syariat Islam tidak mengatur tata cara pengelolaan negara. Berkaitan dengan ini, Muhammadiyah mendasarkan pandangannya pada hadīth Nabi: antum a'lamu bi-umūr dunyäkum. Meski begitu Muhammadiyah mengakui bahwa ada juga orang-orang di dalam Muhammadiyah yang menginginkan pengelolaan negara dikembalikan seperti masa-masa klasik Islam, tetapi hanya sebagian kecil saja. Muhammadiyah berpendapat bahwa syariat tidak menentukan bagaimana bentuk negara, bahkan hal ini tidak diatur sama sekali dalam syariat Islam. Bagi Muhammadiyah, bentuk negara Indonesia ini merupakan bentuk yang sangat ideal sehingga tidak penting berbicara mengenai masalah penerapan syariat Islam dalam arti formal. ${ }^{43}$

Dalam hal demokrasi, Muhammadiyah sangat menerima konsep dan penerapan demokrasi di Indonesia. Meskipun secara terminologi istilah demokrasi berasal dari luar, namun secara substantif, nilai-nilai dasar demokrasi itu terdapat dalam al-Qur'ān dan Sunnah, seperti kata-kata shürā, keadilan, dan persamaan derajat. Dalam kata shürā misalnya, terkandung makna partisipasi, yakni semua kita sama di

(Dekan FAI UMSU), Wawancara, Sumatera Utara 8 Agustus 2018; Lazuardi Harahap (Wakil Ketua PD Muhammadiyah Tapanuli Selatan), Wawancara, Sumatera Utara 11 Agustus 2018; Amil Mahzul Nasution (Ketua PD Muhammadiyah Padangsidimpuan), Wawancara, Sumatera Utara 12 Agustus 2018; Masdiarman Piliang (Ketua PD Kota Sibolga), Wawancara, Sumatera Utara 13 Agustus 2018.

42 Ibid.

${ }^{43}$ Ibid. 
depan hukum dan sama-sama dibenarkan untuk berbicara dan mengemukakan pendapat dalam kesamaan level, persamaan derajat, persamaan ruang, dan sebagainya. Hal ini merupakan substansi demokrasi yang sesuai dengan prinsip-prinsip shürā yang diterima Muhammadiyah. Karena itu, sistem pemilihan kepengurusan di Muhammadiyah juga menerapkan demokrasi melalui sebuah pemilihan, di mana tidak ada otoritas pribadi di sana dan tidak ada hegemoni suku dan pemikiran. ${ }^{44}$

Secara organisatoris Muhammadiyah tidak setuju, bahkan tidak bersimpati sama sekali degan kelompok-kelompok tertentu yang mengintrodusir, mempropagandakan, menggerakkan, apalagi melakukan berbagai gerakan dan aksi ingin mendirikan negara Islam, seperti yang dilakukan oleh Hizbut Tahrir Indonesia (HTI) yang ingin mendirikan khiläfah Islämiyah. Muhammadiyah bahkan merasa resah dengan adanya gerakan transnasional dan internasional yang mencoba untuk mengekspor ideologi tertentu ke berbagai daerah dan negara dengan tujuan ingin mendirikan negara Islam. Dalam berbagai forum resmi Muhammadiyah, pimpinan pusat dan wilayah seluruh Indonesia menolak pahan dan gerakan yang ingin mendirikan negara Islam atau khiläfah Islamiyah seperti digulirkan HTI dan ISIS. Secara faktual pun, menurut Muhammadiyah, fakta empiris memperlihatkan bahwa tidak ada satu pun model negara Islam yang ideal untuk dicontoh. ${ }^{45}$

\section{Jihad dan Perang}

Contoh ideal yang diperlihatkan Kiai Haji Ahmad Dahlan, seperti menghilangkan rasa lapar dan haus serta menyantuni anak-anak yatim, merupakan contoh jïhäd yang nyata bagi Muhammadiyah. Dalam konteks ini, menurut Muhammadiyah jihäd adalah mewujudkan teologi al-Mā'un dalam kehidupan sehari-hari. Dalam sejarah Muhammadiyah, wujud konkret jibäd itu adalah mendirikan panti asuhan, sekolah, dan mendirikan rumah sakit. Jadi Muhammadiyah lebih memaknai jibäd dalam konteks aksi ketimbang gerakan-gerakan radikal yang cenderung merugikan diri pribadi dan orang lain. Inilah makna jïhäd yang sesungguhnya bagi Muhammadiyah. ${ }^{46}$

Berkaitan dengan syarat-syarat jïhäd dalam Islam, Muhammadiyah tidak melihatnya dalam makna fiqh, tetapi pada substansi yang lebih

\footnotetext{
${ }^{44}$ Ibid.

${ }^{45}$ Ibid.

${ }^{46} \mathrm{Ibid}$
} 
universal. Bagi Muhammadiyah, siapa saja bisa melakukan jïhäd, asalkan ia mukmin dan melakukan suatu perbuatan yang bermanfaat bagi dirinya dan orang lain sehingga menghasilkan kemaslahatan dan dilakukan secara maksimal sehingga ia letih dan mengalami kesulitankesulitan. Inilah sesungguhnya yang dimaksud dengan jubd atau jïhäd itu dalam pandangan Muhammadiyah. ${ }^{47}$

Muhammadiyah sangat tidak setuju dan mengecam berbagai tindakan kekerasan dan pembunuhan yang dilakukan siapa atau kelompok mana saja dengan atas nama jïhäd. Bagi Muhammadiyah, semua pelaku tindakan kekerasan dan pembunuhan atas nama jïhäd itu sangat mencedarai rasa kemanusiaan dan bertentangan dengan nilainilai keimanan dan keislaman. Dalam konteks ini, paham dan gerakan yang mengatas namakan jïhäd untuk tindakan kekerasan dan pembunuhan, menurut Muhammadiyah adalah paham dan gerakan yang menyesatkan. Bagi Muhammadiyah, orang beriman (mukmin) tidak akan pernah menyetujui, apalagi melakukan perbuatan seperti itu. ${ }^{48}$

Secara bahasa, kata mu'min itu terambil dari kata amana yang bisa berarti aman dan/atau keamanan. Karenanya, seorang mukmin itu adalah orang yang memiliki komitmen kuat terhadap keamanan, yakni orang-orang yang ketika ia hidup dan hadir ditengah-tengah masyarakat, ia mendatangkan dan memelihara keamanan bagi diri dan masyarakatnya. Bila dianalisis lebih lanjut, kata mu'min itu juga seakar dengan kata amānah. Artinya, orang mu'min ketika ia hidup di tengahtengah masyarakat kemudian kepadanya diberi amanah, ia tidak akan pernah berkhianat atau melakukan penghianatan terhadap amanah yang diberikan kepadanya. Karenanya, bagi Muhammadiyah mu'min itu bukan hanya sekadar beriman kepada Allah dan rasul-Nya, tetapi makna mu'min itu lebih ditekankan pada aksi sosial yang berhasil ia wujudkan di tengah-tengah masyarakat. Dalam al-Qur'ān, kata mu'min itu selalu berkatan dengan etika publik sebagaimana dinyatakan Allah dalam al-Qur'ān. ${ }^{49}$

Sesungguhnya beruntunglah orang-orang yang beriman, yaitu orang-orang yang khusyuk dalam salatnya, menjauhkan diri dari (perbuatan dan perkataan) yang tiada berguna, menunaikan zakat, menjaga kemaluannya, kecuali terhadap istri-istri mereka atau budak yang mereka miliki, maka sesungguhnya mereka dalam hal

\footnotetext{
${ }^{47}$ Ibid.

${ }^{48}$ Ibid.

${ }^{49}$ Ibid.
} 
ini tiada tercela. Barangsiapa mencari yang di balik itu, maka mereka itulah orang-orang yang melampaui batas. Orang-orang yang memelihara amanat-amanat (yang dipikulnya) dan janjinya, dan orang-orang yang memelihara sembahyangnya. Mereka itulah orang-orang yang akan mewarisi surga Firdaus dan kekal berada di dalamnya (Q.S. al-Mu'minūn [23]: 1-11).

Dari ayat-ayat tersebut secara jelas dapat dipahami bahwa kriteria mu'min itu sangat terkait dengan etika publik, yakni penegakan akhlak dalam kehidupan sosial di tengah-tengah masyarakat, seperti menjauhkan diri dari perbuatan dan perkataan yang tidak berguna, menunaikan zakat, menjaga kemaluan, memelihara amanah dan menunaikan janji. Karenanya selain iman kepada Allah dan rasul-Nya, mu'min itu adalah orang yang sangat berkomitmen memelihara kebersihan diri, penegakan keadilan, kepedulian terhadap sesama, dan penegakkan hukum di tengah-tengah masyarakat. Bagi Muhammadiyah, mu'min bukan hanya sekadar simbol, tetapi aksi sosial di tengah-tengah masyarakat. ${ }^{50}$

Dalam konteks käfir, bagi Muhammadiyah ada dua macam. Pertama, käfir 'aqäid, yakni yang tidak berkeyakinan kepada Allah swt. Kedua, käfir dalam makna inkar. Dalam konteks ini, seorang yang mengaku Muslim pun bisa disebut käfir. Misalnya seorang Muslim yang diberi nikmat oleh Allah kemudian ia tidak mampu menggunakan dan mensyukuri nikmat itu sesui petunjuk Allah, maka ia sesungguhnya juga disebut käfir. Sama halnya, ketika Allah menganugerahkan kepada kita negara ini, kemudian kita tidak mengelolanya secara baik dan berperilaku korup misalnya, maka itu pun sama dengan keäfir. Karenanya, bagi Muhammadiyah, terminologi käfir tidak hanya bisa dilabelkan kepada non-Muslim, tetapi juga Muslim. Tetapi, bagi Muhammadiyah, seluruh umat Islam terutama warga Muhammadiyah dilarang melontarkan kata-kata käfir kepada siapa saja, baik käjir dalam pengertian pertama maupun kedua. Dalam pandangan Muhammadiyah, hal itu sesuai dengan akhlak Islam dan etika sosial. Di samping itu, melontarkan kata-kata käfir kepada siapa saja jelas akan menimbulkan amarah, sakit hati, dan permusuhan. ${ }^{51}$

Berkaitan dengan hubungan Muslim dengan non-Muslim, ada dua sikap yang diambil Muhammadiyah. Pertama, dalam konteksnya dengan non-Muslim yang bersahabat baik dan tidak memusuhi umat Islam, maka Muhammadiyah dan seluruh warganya wajib membangun

${ }^{50} \mathrm{Ibid}$.

${ }^{51}$ Ibid. 
hubungan sosial yang baik atas dasar kemanusiaan. Dalam konsepsi Muhammadiyah, kepada siapapun warga Muhammadiyah wajib menjalin hubungan sosial dengan baik. Muhammadiyah tidak ragu menjalin hubungan baik dengan siapapun atas dasar kemanusiaan. Keteladanan seperti ini telah dicontohkan dengan baik oleh para tokoh elit Muhammadiyah sejak Kiai Ahmad Dahlan sampai Haidar Nasir. Semua tokoh elit Muhammadiyah bersahabat baik dengan tokoh-tokoh dari berbagai agama lain, seperti Katolik, Protestan, Hindu, dan Buddha. ${ }^{52}$

Kedua, terhadap non-Muslim yang tidak bersahabat, bahkan mungkin memusuhi umat Islam, Muhammadiyah tidak mengambil sikap yang sama dengan mereka. Dalam konteks ini, secara organisatoris, Muhammadiyah mengambil sikap mendukung upayaupaya yang dilakukan pemerintah dalam menjembatani penciptaan suasana kehidupan yang saling menghormati atas dasar kemanusiaan. Jika muncul permasalahan, Muhammadiyah pun mendukung setiap upaya pemerintah untuk meminimalisir atau mengatasinya. Muhammadiyah akan memberikan beberapa masukan kepada pemerintah atau desakan kepada pihak-pihak tertentu yang memiliki otoritas dalam hal ini guna membantu mengatasinya. Contoh untuk hal ini misalnya kekejaman zionis Israel terhadap Muslim Palestina. Dalam kasus ini, Muhammadiyah mengajukan saran dan dukungan kepada pemerintah agar pemerintah segera memainkan peran mediasi untuk mendesak Israel agar menghentikan tindakan kekerasan dan kezaliman itu. Contoh kedua berkaitan dengan kekejaman terhadap Muslim Rohingya di Myanmar. Di samping mendorong pemerintah untuk memediasi, dalam kasus ini, tokoh Muhammadiyah, Din Syamsudin, berangkat ke Myanmar menemui San Su Kyi, tokoh agama Buddha yang mendapat hadiah nobel perdamaian, untuk berdialog langsung dan mengajukan ragam desakan agar kekerasan terhadap Muslim Rohingya segera dihentikan. ${ }^{53}$

\section{Negara Barat dan Kafir}

Muhammadiyah tidak membatasi diri bergaul dengan siapapun, termasuk negara-negara Barat yang notabene non-Muslim. Bagi Muhammadiyah, jalinan komunikasi dan kerjasama dengan semua negara di dunia, termasuk negara-negara Barat, adalah penting. Upaya

\footnotetext{
52 Ibid.

${ }^{53}$ Ibid.
} 
mewujudkan suasana kehidupan yang aman, damai, dan harmoni tidak akan pernah terwujud tanpa ada dan berlanjutnya hubungan baik dan kerjasama. Karena itu, tokoh-tokoh Muhammadiyah tidak hanya sekadar berinteraksi, tetapi juga berkomunikasi secara aktif dan bekerjasama dengan tokoh-tokoh berbagai agama untuk mewujudkan suasana kehidupan dunia yang aman, damai, dan harmoni itu. Selama hubungan dan kerjasama itu memberi manfaat bagi kemanusiaan, Muhammadiyah dan semua warganya tidak akan ragu-ragu untuk menjalin hubungan dan bekerjasama. Bagi Muhammadiyah, membangun hubungan bilateral dan multilateral atas dasar kemanusiaan dengan berbagai negara Barat tidak ada persoalan sama sekali. Atas dasar itu, tidak ada alasan bagi Muhammadiyah dan warganya untuk memusuhi Barat. ${ }^{54}$

Terhadap negara-negara Barat yang tidak bersahabat bahkan memusuhi umat Islam pun, Muhammadiyah tidak pernah merespons dengan perbuatan yang sama, karena Muhammadiyah adalah gerakan kultural. Dalam konteks ini, Muhammadiyah hanya bisa merespons dengan melakukan desakan-desakan tertentu kepada pihak tertentu yang memiliki otoritas. Misalnya kepada zionis Israel yang melakukan kekerasan dan kezaliman terhadap umat Islam di Palestina. Dalam hal ini, Muhammadiyah tidak pergi berperang ke Palestina, tetapi memberikan dukungan yang sangat kuat kepada pemerintah agar negara memainkan peran mediasi untuk mewujudkan perdamaiandisana. Contoh lain, Din Syamsudin pernah berkunjung ke Myanmar dan menemui San Syu Ki terkait dengan kekerasan dan kezaliman yang dilakukan warga Vietnam terhadp Muslim Rohingya. Dalam hal ini, Din Syamsudin hanya melakukan desakan-desakan bukan pada ranah aksi. ${ }^{55}$

Dalam konteks memilih pemimpin non-Muslim, di kalangan warga Muhammadiyah terdapat dua pendapat yang berbeda. Pertama, pendapat yang membolehkan dan kedua, yang tidak membolehkan. Kedua pendapat ini berkembang dikarenakan dalam konteks memilih pemimpin, Muhammadiyah tidak mengatur secara tegas. Karenanya terdapat tokoh atau elit-elit Muhammadiyah dengan pemikiran yang jernih tanpa dibarengi dengan kepentingan-kepetingan tertentu (politik), membolehkan umat Islam memilih pemimpin non-Muslim. Namun elit Muhammadiyah yang lain, yang pemikirannya dilatari oleh

\footnotetext{
54 Ibid.

55 Ibid
} 
kepentingan-kepentingan politik tertentu, atau setidaknya dipengaruhi oleh situasi dan kondisi politik tertentu, tidak membolehkannya. Sebagai contoh, Syafici Maarif dengan pemikirannya yang jernih dan murni akademis membolehkan umat Islam memilih pemimpin nonMuslim pemikiran ini relatif sama dengan Din Syamsudin yang membolehkan memilih pemimpin non-Muslim selama ia memiliki kapasitas dalam membangun nilai-nilai kemanusiaan. Berbeda dengan itu, Amin Rais sebagai salah seorang tokoh Muhammadiyah yang sangat cerdas tetapi sedikit dipengaruhi oleh situasi dan kondisi politik, justru tidak membenarkan umat Islam memilih pemimpin dari kalangan non-Muslim. ${ }^{56}$

Dalam konteks boleh tidaknya mematuhi pemimpin non-Muslim, menurut Muhammadiyah, sepanjang pemimpin itu dipilih oleh rakyat dan ia memimpin sesuai dengan konstitusi, maka tidak ada halangan bagi Muhammadiyah dan warganya untuk mematuhinya. Dalam hal pemimpin itu bertindak zalim dan berada di luar konstitusi, maka Muhammadiyah dan warganya akan meluruskannya sesuai dengan hukum yang berlaku di NKRI. ${ }^{57}$

Di lingkungan Muhammadiyah tidak pernah dikenal terminologi bom bunuh diri, apalagi dikaitkan dengan jïhäd. Sepanjang sejarahnya, Muhammadiyah tidak pernah mengenal, apalagi menggunakan istilah ini. Karena itu, Muhammadiyah sangat mengutuk keras perbuatan oknum dan/atau kelompok-kelompok tertentu yang melakukan bom bunuh diri atas nama jihäd..$^{58}$

Dalam kenyataannya, dari sejumlah kasus bom bunuh diri yang terjadi, baik di Indonesia maupun di berbagai negara lain, semuanya telah menimbulkan dampak negatif yang sangat luas. Tidak hanya kerugian material, bom bunuh diri itu juga telah mengakibatkan kematian begitu banyak korban, memunculkan rasa ketakutan dan kekhawatiran di mana-mana, merusak hubungan kemanusiaan antaragama, bangsa, dan negara, bahkan merusak dan menistakan agama Islam. Kasus-kasus bom bunuh diri itu bahkan dijadikan alasan dan/atau pembenaran bagi kelompok-kelompok tertentu untuk menjustifikasi bahwa Islam dan/atau umat Islam adalah teroris. Karenanya, menurut Muhammadiyah, tidak ada sedikit pun manfaat

\footnotetext{
${ }^{56} \mathrm{Ibid}$

${ }^{57}$ Ibid.

${ }^{58}$ Ibid.
} 
perbuatan bom bunuh diri itu terhadap umat Islam dan kemanusiaan. ${ }^{59}$

Secara normatif, menurut Muhammadiyah, hukum bunuh diri itu haram sama keharamannya dengan membunuh orang lain. Karena itu Muhammadiyah sangat tidak sepakat dengan perilaku bom bunuh diri, apalagi dilakukan atas nama jïhäd. Dengan mengutip Q.S. al-Mā’idah [5]: 32, Muhammadiyah menyatakan secara tegas bahwa membunuh seorang manusia saja sama halnya dengan membunuh manusia secara keseluruhan. ${ }^{60}$

\section{Penanggulangan Radikalisme}

Untuk menciptakan suasana kehidupan masyarakat, bangsa, dan negara yang aman, damai, dan harmoni, maka deradikalisasi merupakan suatu upaya sangat penting dan harus dilakukan. Dalam konteks ini, ada dua upaya yang telah dilakukan Muhammadiyah. Pertama, secara internal, Muhammadiyah memberdayakan pelaksanaan pengajian rutin untuk seluruh warga Muhammadiyah dari mulai tingkat ranting sampai pusat, yang tidak hanya melibatkan laki-laki tetapi juga perempuan, baik anak-anak, para pemuda, dan orang tua. Masih dalam konteks pembinaan internal ini, Muhammadiyah juga memberdayakan pelaksanaan pendidikan Islam dan keMuhmmadiayah-an di seluruh institusi pendidikan formal Muhammadiyah, dari mulai tingkat dasar sampai perguruan tinggi. Dalam konteks ini, nilai-nilai karakter yang ditanamkan kepada peserta didik adalah nila-nilai Islam rạmah li al-álamin yang menekankan keadilan, persaudaraan, persamaan, dan toleransi. ${ }^{61}$

Secara eksternal, dalam rangka deradikalisasi, Muhammadiyah Sumatera Utara tidak hanya sekadar melibatkan diri, tetapi juga menyelenggarakan sejumlah kegiatan dialog antar-umat beragama. Dialog tersebut melibatkan kalangan Muslim, Katolik, Protestan, Hindu, Buddha, dan kepercayaan lain yang ada di daerah ini. Dialog tersebut berorientasi pada upaya bagaimana menciptakan dan membangun peradaban bersama, bagaimana membangun persaudaraan, dan bagaimana menghormati nilai-nilai kemanusiaan, dan toleransi. Hasil dialog ini disosialisasikan tidak hanya di tingkat wilayah, tetapi juga daerah, cabang, dan ranting Muhammadiyah

\footnotetext{
${ }^{59}$ Ibid.

${ }^{60} \mathrm{Ibid}$

${ }^{61} \mathrm{Ibid}$
} 
seluruh Sumatera Utara. Dalam kegiatan-kegiatan seperti ini, Muhammadiyah senantiasa menekankan konsep Islam wasatīyah. Kemudian usaha lain yang juga dilakukan adalah memberikan masukan-masukan kepada pemerintah daerah melalui berbagai forumforum resmi dan tidak resmi sebagai bagian dari tanggung jawab Muhammadiyah dalam membangun kehidupan yang aman, damai, dan harmoni antar-masyarakat Sumatera Utara yang beragam etnis, bangsa, budaya, bahkan agama. ${ }^{62}$

Dalam konteks deradikalisasi, problema pokok yang dihadapi Muhammadiyah adalah sulitnya mensosialisaikan berbagai gagasan, konsep, dan upaya penangulangan yang telah dibicarakan dan diputuskan ke masyarakat di tingkat grass root. Bagaimanapun, Muhammadiyah mengakui bahwa pemahaman ke-Islaman dan keMuhammadiyahan masyarakat sampai ke akar rumput masih beragam. Semuanya banyak bergantung kepada tokoh-tokoh dan para muballigh yang intens berinteraksi dan berkomunikasi dengan mereka. Sementara itu, belum semua tokoh dan muballigh yang mampu menangkap ide-ide cerdas dan bernas dari pimpinan Muhammadiyah untuk disosialisasikan kepada masyarakat, terutama berkaitan dengaan isu-isu yang sensitif berkenaan dengan umat beragama. Para tokoh lokal dan muballigh tersebut baru memiliki pemahaman tentang Muhammadiyah secara umum. Di kalangan muballigh Muhammadiyah sendiri, mereka umumnya baru menguasai Islam pada materi-materi tertentu dalam konteks fiqh, tetapi dalam konteks mu'amalah dan siyāsah seperti bagaimana membangun hubungan Islam dengan negara, bagaimana membangun hubungan baik dengan umat beragama lain, dan berbagai isu-isu aktual lain yang sedang berkembang belum mereka kuasai secara baik. ${ }^{63}$

Dalam hubungannya dengan berbagai upaya deradikalisasi yang dilakukan pemerintah, Muhammadiyah merespons secara positif. Respons tersebut tidak hanya bersifat verbal dalam bentuk menyampaikan saran dan pendapat, tetapi juga kesediaan terlibat aktif dalam berbagai wadah dan institusi yang dibentuk pemerintah. Tokoh dan pengurus Muhammadiyah yang terlibat dalam Forum Kerukunan Umat Beragama misalnya, merupakan representasi dari Muhammadiyah dalam rangka deradikalisasi. ${ }^{64}$

\footnotetext{
${ }^{62}$ Ibid.

${ }^{63}$ Ibid.

${ }^{64}$ Ibid.
} 
Masih dalam konteks deradikalisasi yang dilakukan pemerintah, kebeadaan Badan Nasional Penanggulangan Terorisme (BNPT) dan Densus 88 mendapat catatan khusus dari Muhammadiyah Sumatera Utara. Sebagai paham, radikalisme merupakan suatu konsep yang ditanamkan dalam rentang waktu yang relatif lama. Proses penanaman itu bisa jadi dilakukan melalui pengajaran, pelatihan, dan indoktrinasi. Manakala konsep itu telah tertanam dalam mindset seseorang, maka upaya untuk menghilangkannya tidaklah mudah. Karena itu, dalam upaya deradikalisasi di bidang pemahaman ini, maka sudah seharusnya BNPT bekerjasama dan melibatkan Muhammadiyah serta organisasiorganisasi keislaman lainnya. Pengalaman Muhammadiyah dan organisasi-organisasi Islam lainnya dalam penyelenggaraan pendidikan, pengkaderan, dan pengajian, mungkin bisa sangat bermanfaat membantu BNPT, baik dalam hal: 1) memahami akar permasalahan munculnya radikalisme, 2) meluruskan kembali pemahaman yang benar tentang Islam sebagai agama yang anti radikalisme, dan 3) melakukan penyadaran lewat berbagai pelatihan dan/atau pengkaderan ulang untuk meminimalisir dan menghapus paham radikalisme. Kemudian dalam konteks penanganan, cara-cara yang dilakukan Densus 88 dalam menindak pelaku radikalisme dan terorisme, Muhammadiyah menyarankan sebaiknya mengacu kepada penegakan hak-hak asasi manusia dan penghormatan terhadap harkat dan martabat kemanusiaan. ${ }^{65}$

\section{Catatan Akhir}

Secara umum dapat disimpulkan bahwa Muhammadiyah di Sumatera Utara yang diteliti merupakan organisasi Islam moderat yang anti-paham dan gerakan radikalisme. Muhammadiyah menegaskan bahwa NKRI merupakan bentuk ideal bagi Indonesia, dan tidak menghendaki Indonesia diubah menjadi negara Islam. Muhammadiyah, sejak awal berdiri hingga kini tidak pernah berpikir tentang negara Islam. Bagi Muhammadiyah NKRI merupakan model negara ideal mempersatukan kelompok-kelompok masyarakat yang berbeda suku, bangsa, budaya, dan agama dalam satu negara kesatuan. Muhammadiyah memandang bahwa NKRI merupakan anugerah Tuhan yang harus dirawat dan disyukuri. Muhammadiyah bahkan menegaskan bahwa NKRI merupakan Dār al-'Ahd wa al-Shahädah, yaitu tempat pembuktian atau kesaksian bagi mewujudkan NKRI

65 Ibid. 
sebagai tempat yang aman dan damai untuk semua komponen bangsa yang berbeda suku, bangsa, budaya, dan agama.

\section{Daftar Rujukan}

'Sejarah Perkembangan Muhammadiyah di Sumatera Utara' dalam http://sumut.muhammadiyah.or.id/content-3-sdet-sejarah.html

Bolshova N.N., "The Rise of Anti-Islamic Protests in Europe under the Refugee Crisis: Case of "Pegida" Movement in Germany", Political Studies, No. 3, 2016.

Chaliand, Gerard. "Jihadism in the Age of ISIS," dalam Gerard Chaliand dan Arnaud Blind, The History of Terrorism: From Antiquity to ISIS. California: University of California Press, 2016.

Darmadji, Ahmad. "Pondok Pesantren dan Deradikalisasi Islam di Indonesia," Millah: Jurnal Studi Agama, Vol. 11, No. 1, 2011.

Golose, Petrus Reinhard. Deradikalisasi Terorisme: Humanis, Soul Approach dan Menyentuh Akar Rumput. Jakarta: YPKIK [Yayasan Pengembangan Kajian Ilmu Kepolisian], 2010.

Gunderson, Cory Gideon. Terrorist Groups. USA: Abdo dan Daugters, 2003.

Haitamy, M. Nur. 'Muhammadiyah Daerah Sumatera Timur' dalam 30 Tabun Mubammadiyah di Daerah Sumatera Timur. Medan: Panitia Besar Peringatan, 1957.

Harahap, Lazuardi (Wakil Ketua PD Muhammadiyah Tapanuli Selatan). Wawancara. Sumatera Utara 11 Agustus 2018.

Hilmy, Masdar. "Manufacturing The 'Ontological Enemy': SocioPolitical Construction of anti-Democracy Discourses among HTI Activists in Post-New Order Indonesia", Journal of Indonesian Islam, Vol. 3, No. 2, 2009.

----. "Quo-Vadis Islam Moderat Indonesia? Menimbang Kembali Modernisme Nahdlatul Ulama dan Muhammadiyah", MIQOT: Jurnal Ilmu-ilmu Keislaman, Vol. 36, No. 2, 2012.

-----. "Whither Indonesia's Islamic Moderatism? A Reexamination on the Moderate Vision of Muhammadiyah and NU", Journal of Indonesian Islam, Vol. 7, No. 1, 2013.

Lukens-Bull, Ronald. "The Traditions of Pluralism, Accomodation, and Anti-Radicalism in the Pesantren Community," Journal of Indonesian Islam, Vol. 2, No. 1, 2008. 
Mu'thi, Abdul. "30 Tahun Muhammadiyah di Daerah Sumatera Timur," dalam 30 Tabun Muhammadiyah di Daerah Sumatera Timur. Medan: Panitia Besar Peringatan, 1957.

Mursalin, Ayub dan Katsir, Ibn. "Pola Pendidikan Keagamaan Pesantren dan Radikalisme: Studi Kasus Pesantren-pesantren di Provinsi Jambi", Kontekstualita: Jurnal Penelitian Sosial Keagamaan, Vol. 25, No. 2, 2010.

Nasution, Amil Mahzul (Ketua PD Muhammadiyah Padangsidimpuan). Wawancara. Sumatera Utara 12 Agustus 2018.

Nasution, Hasyimsyah (Ketua PW Muhammadiyah Sumatera Utara). Wawancara. Sumatera Utara 19 Juli 2018.

Nasution, Tanwir Ahmad. Sejarah Berdirinya Daerah Mubammadiyah Kabupaten Tapanuli Selatan. t.t.: t.tp., 2005.

Piliang, Masdiarman (Ketua PD Kota Sibolga). Wawancara. Sumatera Utara 13 Agustus 2018.

Pimpinan Wilayah Muhammadiyah Sumatera Utara, 'Rekapitulasi Data Amal Usaha Pimpinan Wilayah Muhammadiyah Sumatera Utara' dalam Laporan Pimpinan Wilayah Muhammadiyah Sumatera Utara Periode 2005-2010 pada Musyawarah Wilayah ke-11 Pimpinan Wilayah Muhammadiyah Sumatera Utara. Medan: Pimpinan Wilayah Muhammadiyah Sumatera Utara, 2010.

Pimpinan Wilayah Muhammadiyah Sumatera Utara, Laporan Pimpinan Wilayah Muhammadiyah Sumatera Utara Periode 2005-2010. Medan: Pimpinan Wilayah Muhammadiyah Sumatera Utara, 2011.

Pimpinan Wilayah Muhammadiyah Sumatera Utara, Laporan Pimpinan Wilayah Mubammadiyah Sumatera Utara Tabun 2016. Medan: Pimpinan Wilayah Muhammadiyah Sumatera Utara, 2016.

Pulungan, Abbas et. al. Sejarah dan Dinamika Organisasi Islam di Sumatera Utara. Medan: Institut Agama Islam Negeri Sumatera Utara, 2005.

Qarib, Muhammad (Dekan FAI UMSU). Wawancara. Sumatera Utara 8 Agustus 2018.

Qodir, Zuly. "Gerakan Salafi Radikal dalam Konteks Islam Indonesia: Tinjauan Sejarah", Islamica: Jurnal Studi Keislaman, Vol. 3, No. 1, 2008.

Rusli, "Indonesian Salafism on Jihad and Suicide Bombings," Journal of Indonesian Islam, Vol. 8, No. 1, 2014.

S., Irwan (Sekretaris Umum PW Muhammadiyah Sumatera Utara). Wawancara. Sumatera Utara 23 Juli 2018. 
Saifulah. "Dakwah Multikultural Pesantren Ngalah" Islamica: Jurnal Studi Keislaman, Vol. 8, No. 2, 2014.

Siddik, Dja'far. "Dinamika Organisasi Muhammadiyah di Sumatera Utara", Journal of Contemporary Islam and Muslim Societies, Vol. 1, No. $1,2017$.

Smith, Christopher. "Anti-Islamic Sentiment and Media Framing during the 9/11 Decade," dalam Journal of Religios and Society, Vol. $15,2014$.

Suara Muhammadiyah dan Majelis Pendidikan Kader PP Muhammadiyah, Manhaj Gerakan Mubammadiyah Ideologi, Khittah, dan Langkah. Yogyakarta: Suara Muhammadiyah, 2010.

Suharto, Toto. "Gagasan Pendidikan Muhammadiyah dan NU sebagai

Potret Pendidikan Islam Moderat di Indonesia", Islamica: Jurnal Studi Keislaman, Vol. 9, No. 1, 2014.

Susanto, Edi. "Kemungkinan Munculnya Paham Islam Radikal di Pondok Pesantren," dalam Tadris: Jurnal Pendidikan Islam, Vol. 2, No. 1, 2007, 1-19.

Syoedja, Haji Muhammad. Cerita tentang Kiyai Abmad Dablan: Catatan Haji Mubammad Syoedja. t.t.: t.tp., t.th.

Syukur, Abdul. "Gerakan Dakwah dalam Upaya Pencegahan Dini terhadap Penyebaran dan Penerimaan Islamisme Kelompok Radikal-Terorisme di Lampung", Analisis: Jurnal Studi Keislaman, Vol. 15, No. 1, 2015.

Thran, Malte dan Boehnke, Lukas. "Reactive Community Mobilization in Europe: the Case of the English Defence League," Journal Behavioral Sciences of Terrorism and Political Aggression, Vol. 5, No. 3, 2013.

----. "The Value-Based Nationalism of Pegida," Journal for Deradicalization, Vol. 3, 2015.

Turmudi, Endang dan Sihbudi, Riza (eds.). Islam dan Radikalisme di Indonesia. Jakarta: LIPI Press, 2005.

Vaughn, Bruce. Terrorism in Southeast Asia. Congressional Research Service, 2009.

Wilson, John dan Parashar, Swati. Terrorism in Southeast Asia: Implications for South Asia. Singapura: Pearson Education, 2005.

Zagato, Alessandro. The Event of Charlie Hebdo: Imaginaries of Freedom and Control. New York: Berghahn, 2015. 